\title{
TUTURAN IMPERATIF BERMAKNA POSITIF PADA SPANDUK DI KOTA PEKANBARU
}

\author{
Mhd. Virzha Nafandri Utama ${ }^{1}$, Charlina $^{2}$, Elvrin Septyanti ${ }^{3}$ \\ Universitas Riau, Pekanbaru, Indonesia \\ virzhanafandri16@gmail.com ${ }^{1}$, charlina@lecturer.unri.ac.id ${ }^{2}$ \\ elvrin.septyanti@lecturer.unri.ac.id ${ }^{3}$
}

\begin{abstract}
This study aims to identify the form of imperative speech that positively affects banners in Pekanbaru City and analyses the meaning and function of imperative speech, which positively affects banners in Pekanbaru City. This research includes the form, meaning, and function of imperative speech, which positively affects banners in Pekanbaru City. This type of research is qualitative research with descriptive methods. Data collecting techniques are documentation techniques, by capturing images taken directly, so the real results are obtained. Imperative speech forms with a positive meaning on banners in Pekanbaru City are 33 ordinary imperative, 31 requests, and six prohibitions. Imperative speech with a positive meaning on banners in Pekanbaru City were: 14 orders, 13 requests, ten persuasion, and 33 invitations. Imperative speech functions with a positive meaning on banners in Pekanbaru City are 56 about invitations and 14 about requests.

Key Word : imperative utterances, banners, Pekanbaru.
\end{abstract}

\begin{abstract}
ABSTRAK
Penelitian ini bertujuan untuk mengidentifikasi bentuk tuturan imperatif bermakna positif pada spanduk di Kota Pekanbaru dan menganalisis makna dan fungsi tuturan imperatif bermakna positif pada spanduk di Kota Pekanbaru. Penelitian ini mencakup bentuk, makna dan fungsi tuturan imperatif bermakna positif pada spanduk di Kota Pekanbaru. Jenis penelitian ini adalah penelitian kualitatif dengan metode deskriptif. Teknik pengumpulan data yaitu teknik dokumentasi berupa tangkapan gambar yang diambil secara langsung sehingga diperoleh hasil yang nyata. Teknik analisis data pada penelitian ini yaitu, (1) mengidentifikasi, (2) mengklasifikasi, (3) menganalisis, dan (4) menyimpulkan. Bentuk tuturan imperatif bermakna positif pada spanduk di Kota Pekanbaru adalah : imperatif biasa 33 data, permintaan, 31 data, dan larangan 6 data. Tuturan imperatif bermakna positif pada spanduk di Kota Pekanbaru adalah : suruhan 14 data, permintaan 13 data, bujukan 10 data, dan ajakan 33 data. Fungsi tuturan imperatif bermakna positif pada spanduk di Kota Pekanbaru adalah : ajakan 56 data dan permintaan 14 data.
\end{abstract}

Kata kunci : tuturan imperatif, spanduk, Pekanbaru.

\section{PENDAHULUAN}

Bahasa merupakan hal yang terpenting dalam kegidupan sehari-hari. Pada dasarnya bahasa merupakan sebuah sarana untuk berinteraksi satu sama lain. (Alber \& Febria,
2018) bahasa secara umum mudah untuk dipahami dan hanya dimiliki oleh manusia. Bahasa yang digunakan di Indonesia banyak ragamnya, karena Indonesia merupakan salah satu negara yang mempunyai suku terbanyak di 
dunia. (Andriana, 2020)bahasa dan masyarakat tidak pernah lepas dari yang namanya komunikasi, tanpa adanya bahasa, masyarakat tidak bisa berinteraksi dengan masyarakat lainnya. Di dalam berbahasa, masyarakat menggunakan bahasa untuk berinteraksi, salah satunya dilakukan secara lisan dan tulis.

Bahasa tulis merupakan bahasa lisan yang dituliskan ke dalam sebuah media. Bahasa tulis dapat ditemukan di lingkungan masyarakat, seperti papan pengumuman, surat, dan iklan yang bertujuan untuk memberikan informasi kepada pembaca. Jika pembaca paham dengan pesan yang ada di papan pengumuman, surat, dan iklan tersebut maka komunikasi sudah terjalin. Salah satu bentuk bahasa tulis itu disampaikan melalui tuturan imperatif.

Tuturan imperatif yaitu tuturan yang mengandung maksud memerintah atau meminta agar mitra tutur dapat menuruti sebagaimana yang diinginkan si penutur. Kalimat yang dimaksud memerintah yaitu kalimat yang memberitahukan kepada mitra tutur. (Rahardi, 2005) mengungkapkan bahwa tuturan imperatif mengandung maksud memerintah agar pembaca melakukan perintah yang dituturkan oleh penutur. (Keraf, 1991) mengungkapkan bahwa tuturan imperatif merupakan tuturan yang bermakna perintah agar pembaca dapat melakukan sesuatu yang diinginkan oleh penutur. Penutur mengunakan kalimat perintah dan menginginkan pembaca untuk mengikuti perintah yang dituturkan oleh penutur. Dengan kata lain tuturan imperatif yaitu kalimat yang berisi perintah untuk melakukan sesuatu yang diinginkan oleh penutur.

Tuturan imperatif digunakan dalam kegiatan berbahasa dalam kehidupan seharihari. Banyak cara yang dilakukan untuk melakukan kegiatan berbahasa, yaitu dengan cara langsung dan tidak langsung. Kegiatan berbahasa langsung yaitu penutur langsung meminta secara langsung apa yang diinginkannya, sedangkan kegiatan berbahasa tidak langsung yaitu penutur membuat sebuah perumpamaan kepada lawan tutur dengan maksud yang sama agar mitra tutur memahami maksud dan tujuan si penutur.

Tuturan imperatif dapat ditemukan melalui media luar ruang. Menurut Sandra (dalam Jalita 2018:8) mengungkapkan bahwa media luar ruang merupakan sebuah media yang diletakkan di luar ruangan yang pada saat ini sudah menjadi bagian hidup masyarakat yang bertujuan untuk menyampaikan pesan. Sedangkan menurut Menurut Fandy ( dalam (Jalita, 2017)) mengartikan media luar ruang sebagai media yang berukuran besar dipajang di tempat terbuka seperti pinggir jalan, di pusat keramaian, atau tempat-tempat yang khusus seperti bus, gedung, pagar, dan, tembok. Media luar ruang merupakan suatu media tulis yang berada di luar ruangan, misalnya spanduk yang bertujuan untuk memberi pesan kepada mitra tutur agar mitra tutur mengerti apa yang dituliskan oleh penutur. Dalam (Kamus Besar Bahasa Indonesia (KBBI), n.d.) spanduk merupakan kain yang berisi berita ataupun slogan yang dapat diketahui oleh masyarakat umum. Banyak masyarakat sekarang menggunakan kalimat perintah pada spanduk dengan maksud agar mitra tutur lebih ingin mengikuti perintah yang disampaikan oleh penutur. Masyarakat sekarang cenderung tertarik dengan pesan yang unik agar mitra tutur merespon apa yang diinginkan oleh penutur.

Pada saat ini banyak terlihat pesan pada spanduk yang menggunakan kalimat perintah yang bermakna positif digunakan oleh penutur. Misal "Awas!!! Ada Cendol Buatan Bunda yang Enak Bangettt". Kalimat tersebut merupakan kalimat peintah yang mengandung makna positif dan ditandai dengan kata "Awas!!!". Kalimat tersebut tampak jelas bermakna positif karena menggandung ajakan untuk pembaca agar pembaca datang ke toko penjual cendol. Contoh lainnya dapat kita lihat pada kalimat berikut " Jangan lihat ke kiri, ada laundry Khaisya. Artis-artis pernah laundry di sini". Kalimat tersebut tampak jelas bahwa kalimat tersebut berbeda dengan maksud yang diungkapkan oleh penutur. Kalimat tersebut sehararusnya bermakna pembaca atau mitra 
tutur dilarang untuk melihat kekiri, tetapi dengan adanya konteks kalimat tersebut mempunyai tujuan agar pembaca atau mitra tutur dapat bersinggah ke laundy tersebut. Menurut (Kridalaksana, 2013) konteks yaitu (1) aspek-aspek lingkungan fisik atau sosial yang mengikat ujaran tersebut, dan (2) pengetahuan yang sama-sama dimiliki antara penutur dan mitra tutur sehingga penutur dan mitra tutur paham dengan apa yang dimaksudkan oleh penurur. Sedangkan menurut (Charlina \& Sinaga, 2006) konteks merupakan unsur yang terkait dengan penggunaan bahasa. Konteks merupakan unsur yang terdapat dalam penggunaan bahasa yang di dalamnya terdapat hal-hal yang berada diluar bahasa dan dapat mempengaruhi suatu bahasa.

Berdasarkan kejadian di atas, penulis tertarik melakukan penelitian untuk mengetahui tuturan imperatif bermakna positif pada spanduk di Kota Pekanbaru. Alasan penulis meneliti penelitian ini yaitu banyak spanduk yang berada di masyarakat yang menggunakan kalimat yang unik dan mengandung makna berbeda dengan kalimat yang dituliskan.

\section{METODOLOGI PENELITIAN}

Penelitian ini dilakukan selama lima bulan yaitu dari bulan Juli hingga Desember 2020, Jenis penelitian ini menggunakan metode kualitatif. Menurut Strauss dan Corbin (Pupu, 2009) yang dimaksud dengan penelitian kualitatif yaitu penelitian yang tidak dapat dilaksanakan dengan cara pengukuran statistik. Menurut (Aman, 2007) penelitian kualitaif merupakan penelitian yang mengutamakan masalah, di mana penelitian ini dapat mengungkapkan berbagai informasi dengan rinci dan penuh makna. Penulis mengungkapkan metode ini guna memdeskripsikan adanya tuturan imperatif bermakna positif pada spanduk di Kota Pekanbaru. Adapun sumber data pada penelitian ini yaitu spanduk yang berada di luar ruangan. Data diambil melalui tangkap gambar yang diperoleh dari spanduk yang ada di seluruh Kecamatan yang ada di Kota Pekanbaru.Penelitian ini menggunakan teknik dokumentasi dengan pengambilan data secara langsung dan benar-benar mengandung tuturan imperatif bermakna positif pada spanduk. Pada penelitian ini menggunakan 4 teknik analisis data, yaitu mengidentifikasi, mengklasifikasi, menganalisis, dan menyimpulkan.

\section{HASIL DAN PEMBAHASAN}

Berdasarkan hasil penelitian ditemukan bentuk, makna, dan fungsi tuturan imperatif bermakna positif pada spanduk di Kota Pekanbaru.

\section{A. Bentuk Tuturan Imperatif}

Bentuk tuturan imperatif merupakan merupakan tuturan yang bermakna perintah agar pembaca dapat melakukan sesuatu yang diinginkan oleh penutur. Bentuk tuturan imperatif bermakna positif pada spanduk di Kota Pekanbaru meliputi, bentuk tuturan imperatif biasa, bentuk tuturan imperatif permintaan, dan bentuk tuturan imperatif larangan. Berdasarkan data yang diperoleh dari tuturan imperatif bermakna positif pada spanduk di Kota Pekanbaru, ditemukan 3 bentuk tuturan imperatif dengan data sebanyak 70 data, yang terdiri dari 33 data bentuk tuturan imperatif biasa, 31 data bentuk tuturan imperatif permintaan, dan 6 data bentuk tuturan imperatif larangan.

\section{Imperatif Biasa}

Bentuk tuturan imperatif biasa lazimnya memiliki ciri-ciri sebagai berikut: (1) berintonasi keras, (2) didukung dengan kata kerja dasar, dan (3) berpartikel pengeras -lah. Tuturan imperatif jenis ini dapat berkisar antara imperatif yang sangat halus sampai dengan imperatif yang sangat kasar. Bentuk tuturan imperatif biasa dapat dilihat dari data berikut:

\section{Data (1) "AWAS! HATI-HATI ADA MIE} AYAM BAKSO."

Tuturan pada data (1) termasuk ke dalam bentuk tuturan imperatif biasa. Hal ini dapat dilihat dari adanya intonasi keras yang ditandai 
dengan tanda baca seru (!) dan didukung dengan kata kerja dasar "awas". Tuturan tersebut ditujukan kepada pembaca untuk menghindari warung yang menjual mie ayam bakso.

\section{Permintaan}

Bentuk tuturan imperatif permintaan secara umum ditandai dengan penanda harap. Tuturan imperatif permintaan biasanya menggunakan kadar suruhan sangat halus. Tuturan permintaan ditujukan kepada pembaca agar pembaca menuruti permintaan yang telah di sampaikan oleh penulis. Bentuk tuturan imperatif permintaan dapat dilihat dari data berikut:

$\begin{array}{cccc}\text { Data } & (2) & \text { "HARAP } & \text { PELAN-PELAN } \\ & \text { ANDA } & \text { MEMASUKI } & \text { ZONA } \\ & \text { PARFUM ISI ULANG" (TIBP } & 34 \text { ) }\end{array}$

Tuturan pada data (2) termasuk ke dalam bentuk tuturan imperatif permintaan. Hal ini dapat dilihat dari adanya kata "pelan-pelan" dan disertakan dengan kata "harap" yang merupakan penanda bentuk tuturan imperatif permintaan. Pada tuturan tersebut, penulis spanduk meminta agar pembaca supaya pembaca pelan-pelan saat mengendarai kendarannya karena ada yang menjual parfum isi ulang.

\section{Larangan}

Bentuk tuturan imperatif larangan ditandai dengan penanda jangan. Tuturan imperatif larangan ditujukan kepada pembaca untuk tidak melakukan hal yang telah disampaikan. Bentuk tuturan imperatif larangan dapat dilihat dari data berikut:

Data (3) "HATI-HATI!! JANGAN LIHAT KE KANAN ADA ICE BLEND"

Tuturan pada data (3) termasuk ke dalam bentuk tuturan imperatif larangan. Hal ini dapat ditandai dengan adanya kata "jangan" yang merupakan penanda bentuk tuturan imperatif larangan. Pada tuturan tersebut, pembaca dilarang untuk melihat ke kanan dan berhati-hati karena ada yang menjual Ice Blend. Bentuk Tuturan Imperatif Bermakna Positif Pada Spanduk di Kota Pekanbaru
Tabel 1. Rekapitulasi Bnetuk Tuturan Imperatif

\section{B. Makna Tuturan Imperatif}

\begin{tabular}{|l|l|l|}
\hline NO & $\begin{array}{l}\text { Bentuk } \\
\text { Imperatif }\end{array}$ & Tuturan \\
\hline 1 & Imperatif Biasa & 33 \\
\hline 2 & Permintaan & 31 \\
\hline 3 & Larangan & 6 \\
\hline \multicolumn{2}{|c|}{ Makna tuturan imperatif bermakna }
\end{tabular}

positif pada spanduk di Kota Pekanbaru meliputi, makna suruhan, makna permintaan, bujukan, dan ajakan. Berdasarkan data yang diperoleh, ditemukan 4 makna dengan 70 data yang terdiri dari 14 data bermakna suruhan, 13 data bermakna permintaan, 10 data bermakna bujukan, dan 33 data bermakna ajakan.

\section{Bermakna Suruhan}

Tuturan imperatif suruhan ditandai dengan suruhan secara langsung kepada pembaca. Tuturan imperatif bermakna suruhan dapat dilihat dari data berkut:

Data (1) "STOP DISINI ADA PISANG KEJU 89 "

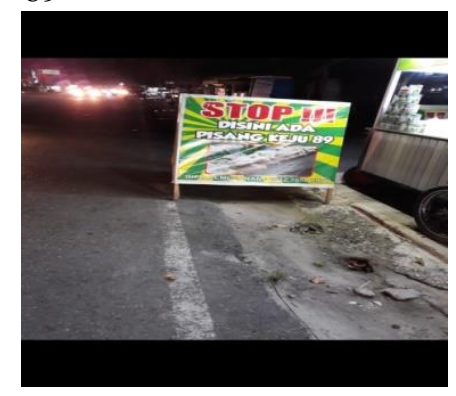

Konteks: Tuturan ini terdapat pada spanduk yang berada di tepi jalan Kecamatan Bukit Barisan, Kota Pekanbaru. Tuturan ini terdapat pada sebuah warung yang menjual pisang keju.

Tuturan pada data (2) termasuk ke dalam tuturan imperatif bermakna suruhan. Hal ini dapat dilihat dari konteks yang melatarbelakanginya dan adanya gambar pisang keju di dalam spanduk tersebut. Kata "stop" mengandung makna suruhan. Tuturan tersebut menyuruh pembaca secara langsung untuk berhenti di warung yang menjual pisang keju. 


\section{Bermakna Permintaan}

Tuturan imperatif permintaan ditandai dengan permintaan secara halus dan biasanya menggunakan kata "harap". Tuturan imperatif bermakna permintaan dapat dilihat dari data berikut:

Data (2) "WARNING!!! Harap pelan- pelan disini ada BENGKEL CLINIC MOTOR INJEKSI““

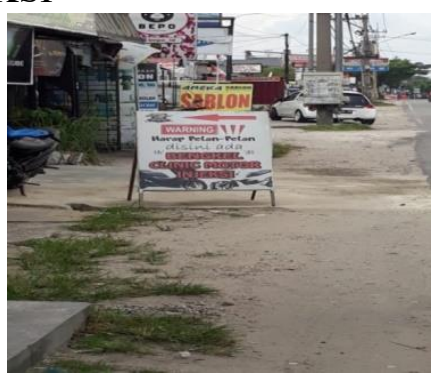

Konteks: Tuturan ini terdapat pada spanduk yang berada di tepi jalan Kecamatan Bukit Barisan, Kota Pekanbaru. Tuturan ini terdapat pada tempat bengkel motor.

Tuturan pada data (2) termasuk ke dalam tuturan imperatif bermakna permintaan. Hal ini dapat dilihat dari konteks yang melatarbelakanginya. Kata "pelan-pelan" mengandung makna permintaan dan adanya kata "harap" yang meminta kepada pembaca untuk menurunkan laju kendaraannya dan singgah untuk memperbaiki motor di bengkel tersebut.

\section{Bermakna Bujukan}

Tuturan imperatif bermakna bujukan bermaksud untuk membujuk pembaca untuk melakukan sesuatu yang disampaikan oleh penutur atau penulis. Tuturan imperatif bermakna bujukan dapat dilihat dari data berikut:

\section{Data (3) "JANGAN LIRIK KE KIRI ADA SALAD SEGAR YANG MENGGIURKAN"}

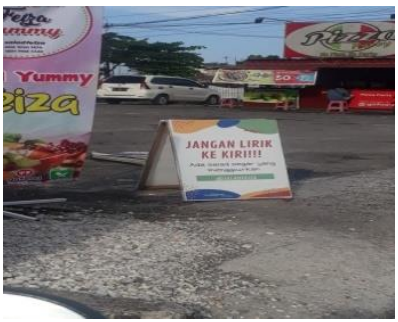

Konteks : Tuturan ini terdapat pada spanduk yang berada di tepi jalan Kecamatan Tampan, Kota Pekanbaru. Tuturan ini terdapat pada sebuah warung yang yang menjual salad yang berada di sebelah kiri jalan.

Tuturan pada data (3) termasuk ke dalam tuturan imperatif bermakna bujukan. Hal ini dapat dilihat dari konteks yang melatarbelakanginya. Kata "jangan" mengandung makna bujukan. Tuturan tersebut berusaha membujuk pembaca untuk melihat ke kiri dan singgah ke warung yang menjual salad tersebut.

\section{Bermakna Ajakan}

Tuturan imperatif bermakna ajakan ditandai dengan tuturan berupa ajakan yang disampaikan oleh penutur supaya mitra tutur mengikuti ajakan yang disampaikan oleh penutur. Tuturan imperatif bermakna ajakan dapat dilihat dari data berikut:

Data (4) "STOP CUCI SEPATU DAN HELM Anda di Sini",

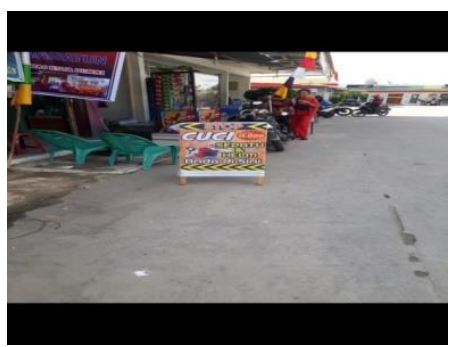

Konteks: Tuturan ini terdapat pada spanduk yang berada di tepi jalan Kecamatan Tampan, Kota Pekanbaru. Tuturan ini terdapat pada toko yang melayani jasa cuci sepatu dan helm.

Tuturan pada data (4) termasuk ke dalam tuturan imperatif bermakna ajakan. Hal ini dapat dilihat dari konteks yang 
melatarbelakanginya. Kata "stop" mengandung makna ajakan. Tuturan tersebut sebenarnya bermaksud mengajak pembaca untuk berhenti ditoko tersebut dan singgah untuk menggunakan jasa cuci sepatu dan helm.

Tabel 2. Makna Tuturan Imperatif Pada Spanduk di Kota Pekanbaru

\begin{tabular}{|c|l|c|}
\hline NO & \multicolumn{1}{|c|}{$\begin{array}{c}\text { Makna Tuturan } \\
\text { Imperatif }\end{array}$} & Jumlah \\
\hline 1 & Bermakna Suruhan & 14 \\
\hline 2 & $\begin{array}{l}\text { Bermakna } \\
\text { Permintaan }\end{array}$ & 13 \\
\hline 3 & Bermakna Bujukan & 10 \\
\hline 4 & Bermakna Ajakan & 33 \\
\hline
\end{tabular}

\section{Fungsi Tuturan Imperatif}

Fungsi tuturan imperatif bermakna positif pada spanduk di Kota Pekanbaru yang ditemukan ada 2, yaitu ajakan dan permintaan. Berdasarkan data yang diperoleh, ditemukan 3 fungsi tuturan imperatif dengan 70 data yang meliputi, 56 data bermakna ajakan dan 14 data bermakna permintaan. Berikut ini disajikan data rekapitulasi fungsi tuturan imperatif bermakna positif pada spanduk di Kota Pekanbaru.

\section{Fungsi Ajakan}

Fungsi ajakan mengacu pada perintah agar mitra tuturnya melakukan tindakan seperti yang disebutkan penuturnya. Fungsi tuturan imperatif ajakan dapat dilihat dari data berikut: Data (1) "STOP!!! Disini ada: Es Kelapa Muda Susu.".

Tuturan pada spanduk yang menjual es kelapa muda berfungsi ajakan. Hal ini dapat dilihat dari konteks yang melatarbelakanginya. Tuturan pada spanduk berfungsi mengajak pembaca untuk singgah ke warung yang menjual es kelapa muda serta membuat pembaca tertarik untuk membeli minuman es kelapa muda di warung tersebut

\section{Fungsi Permintaan}

Fungsi permintaan mengacu pada tuturan yang berisi keinginan penutur terhadap mitra tutur, agar mitra tutur mengikuti pernyataan yang disampaikan oleh penutur. Fungsi permintaan dapat dilihat dari data berikut:

\section{Data (2) "HATI-HATI ADAGUDANG AYAM".}

Tuturan pada spanduk yang menjual ayam potong berfungsi ajakan. Hal ini dapat dilihat dari konteks yang melatarbelakanginya. Tuturan pada spanduk berfungsi mengajak pembaca untuk singgah ke warung yang menjual ayam potong serta membuat pembaca tertarik untuk membeli ayam potong di warung tersebut.

Tabel 3. Fungsi Tuturan Imperatif Pada Spanduk di Kota Pekanbaru

\begin{tabular}{|c|l|c|}
\hline NO & \multicolumn{1}{|c|}{$\begin{array}{c}\text { Fungsi Tuturan } \\
\text { Imperatif }\end{array}$} & Jumlah \\
\hline 1 & Fungsi Ajakan & 56 \\
\hline 2 & Fungsi Permintaan & 14 \\
\hline
\end{tabular}

\section{SIMPULAN}

Berdasarkan data yang di peroleh dari tuturan imperatif bermakna positif pada spanduk di Kota Pekanbaru, ditemukan 33 data bentuk tuturan imperatif biasa, 31 data bentuk tuturan imperatif permintaan, dan 6 data bentuk tuturan imperatif larangan. Selain itu, makna yang ditemukan yaitu 14 data bermakna suruhan, 13 data bermakna permintaan, 10 data bermakna bujukan, dan 33 data bermakna ajakan. Sedangkan fungsi yang ditemukan yaitu 56 data bermakna ajakan dan 14 data bermakna permintaan. Tuturan imperatif biasa, makna ajakan, dan fungsi ajakan yang paling banyak ditemukan dalam penelitian ini. Tuturan imperatif bermakna positif bertujuan untuk menarik perhatian pembaca atau mitra tutur untuk merespon spanduk yang telah dituliskan oleh penutur, supaya pembaca datang dan singgah ke dagangan, jasa, atau warung yang terdapat spanduk tersebut. Oleh karena itu, dengan adanya tuturan imperatif pada spanduk ini akan meningkatkan kreatifitas masyarakat untuk membuat spanduk dengan menggunakan kata-kata yang unik agar pembaca tertarik untuk singgah ke dagangan, 
jasa atau warung yang menggunakan spanduk tersebut.

\section{REFERENSI}

Alber, A., \& Febria, R. (2018). Analisis Kesalahan Berbahasa Tataran Sintaksis dalam Kumpulan Makalah Mahasiswa Universitas Islam Riau. GERAM, 6(2), 77-90.

Aman. (2007). Disampaikan dalam acara Diklat Penulisan Skripsi Mahasiswa Pendidikan Sosiologi yang diselenggarakan oleh HIMA Pendidikan Sejarah FISE UNY pada tanggal $23 \mathrm{Mei}$ 2007. 1 1. 1-11.

Andriana, M. (2020). Reduplikasi Bahasa Melayu Riau Dialek Kampar Kiri. GERAM, 8(1), 27-36.

Charlina \& Sinaga, M. (2006). Analisis Wacana. Pekanbaru: Cendikia Insani.

Jalita. (2017). Pemanfaatan Media Luar Ruang Sebagai Media Penyebaran Informasi. 1. https://repository.arraniry.ac.id/id/eprint/2795/1/JALITA.pdf

Kamus Besar Bahasa Indonesia (KBBI). (n.d.). Https://Kbbi.Web.Id/. Retrieved June 29, 2020, from https://kbbi.web.id/spanduk

Keraf, G. (1991). Tata bahasa rujukan bahasa Indonesia: untuk tingkat pendidikan menengah. Penerbit PT Gramedia Widiasarana Indonesia.

Kridalaksana, H. (2013). Kamus Linguistik (edisi keempat). Gramedia Pustaka Utama.

Pupu, S. R. (2009). Penelitian Kualitatif. Jurnal Eqiulibrum, 5(9).

Rahardi, R. K. (2005). Pragmatik: kesantunan imperatif bahasa Indonesia. Erlangga. 